\title{
Sediment remediation can include no action
}

\author{
Chapman, P.M. \\ Chapema Environmental Strategies Ltd. North Vancouver, BC, Canada. Phone: 1-604-230-7395
}

Received August 09, 2017; Accept October 17, 2017

In Memoriam (1951-2017)

\begin{abstract}
This short Commentary briefly reviews contaminated sediment risks, the 4 factors that determine appropriate remedial alternatives, and situations where the no action (other than monitoring) alternative may be appropriate. References and an example involving mercury-contaminated sediments is provided. Remediation alternatives other than no action should not cause more environmental harm than they prevent.
\end{abstract}

Keywords: sediment, contamination, remediation, risks, benefits.

\section{INTRODUCTION}

Sediment contaminated with substances such as metals and organics to concentrations above sediment quality guidelines (SQGs) or other sediment quality benchmarks is of potential concern. However, contamination (i.e., substances present where they would not normally be found, or above natural background concentrations) is not necessarily pollution (i.e., contamination that results in adverse biological effects), particularly in sediments where contaminant bioavailability can be reduced by binding to sediment constituents (Chapman et al., 1998). Further, SQGs or other benchmarks tend to be conservative - lower concentrations are likely not of concern, while higher concentrations are of possible but not certain concern (Chapman, 2016).

Thus, determining whether contaminated sediment is polluted sediment requires additional, biological assessment (Chapman, 2007). Based on such additional assessment, remediation decisions can be made (i.e., not solely based on SQGs or similar chemistry-only benchmarks). However, such remediation decisions need to consider both the positive and negative aspects of remediation alternatives since no remediation action is environmentally neutral or totally riskfree. The purpose of this Short Communication is to briefly review the various alternatives to sediment remediation and point out that the no action alternative can be the best option in some situations.

\section{DISCUSSION}

Risks from contaminated sediments depend on exposure to biologically available substances from those sediments. Exposure of biota and for humans will come from the surficial sediments, where biological activity occurs, unless there is potential for disturbance and exposure of more contaminated deeper sediments. Exposure can result in toxicity or, for a few organic substances, in biomagnification (i.e., uptake of a contaminant through a food chain resulting in increasing concentrations through three or more trophic levels). Common sediment contaminants that may biomagnify include: organic mercury; PCBs; DDT; and, 2,3,7,8-TCDD. Inorganic substances such as metals do not biomagnify (Chapman, 2008).

There are four key factors that determine what remediation alternative(s) may be appropriate for contaminated sediments: human health risks; acute toxicity; biomagnification potential; and, potential disturbance and exposure of highly contaminated deeper sediments. Possible remediation alternatives are the following, either singly or in combination across contaminated sediment sites: no action (i.e., monitored natural recovery); capping (which can include thick or thin layers, and exposure and toxicity modifying factors such as activated carbon); in situ treatment (which typically does not change chemical concentrations such that contamination remains, but reduces bioavailability or exposure such that pollution is no longer an issue); and, dredging and removal.

*Corresponding author: Peter M. Chapman; e-mail: peter@chapmanenviro.com 
For all of these remedial alternatives, monitoring is an essential component of the process to determine remediation success. Adequate monitoring must (Chapman \& Smith, 2012): characterize pre-remedial trends; compare these to post-remediation conditions; allow a sufficient time-scale to capture recovery; and, include appropriate reference sites / comparisons.

The no action alternative can be appropriate for cases where there is: no human health risk; no acute toxicity; no high biomagnification potential; and, no likely possible future disturbance/exposure of contaminated deeper sediments. Dredging and removal is generally appropriate for cases where these are all factors. Capping and in situ treatment are appropriate where there is human health risk, acute toxicity, and high biomagnification potential, but only if there is no likelihood of deeper sediments being disturbed.

Table 1 briefly summarizes the positive and negative aspects of each of the above possible remediation alternatives. All alternatives need to be considered in a risk:benefit assessment before final decisions on the appropriate remedial alternative are made. For example, although the dredging and removal alternative has appeal for resolving the immediate issue, removal is not total (Bridges et al., 2010) and removed sediments need to be transported, dewatered and disposed of. Similarly, capping requires transport and placement of the capping material.

Further information and guidance on implementing the no action alternative (i.e., monitored natural recovery) is provided in Magar \& Wenning (2006), Magar et al. (2009), and Fuchsman et al. (2014). An example is provided by the Cornwall [ON, Canada] Sediment Strategy for mercurycontaminated sediments (https://www.rrca.on.ca/ files/ file/brochure-Cornwall-Sediment-Strategy.pdf?phpMyA dmin $=415$ bcc74a9c69072ce5800d6de86a905). As noted by Environment and Climate Change Canada (2017) "The Cornwall Sediment Strategy, jointly led by Environment and Climate Change and the Ontario Ministry of the Environment and Climate Change, was completed in 2005. This significant accomplishment, involving scientists from both Environment and Climate Change Canada and the Ontario Ministry of the Environment and Climate Change, established administrative controls to protect contaminated sediments in the river from disturbance by any future waterfront development By allowing cleaner sediment to settle on top of the highly contaminated sediments, the benthos (or riverbed community of organisms, an important part of the aquatic food chain) has been restored."

In summary, if the impacts of the no action alternative will cause less environmental harm than other alternatives and the no action alternative is reasonably possible, it should be the alternative of choice. In particular, the no action alternative should be considered for sensitive, unique environments that could be irreversibly damaged by intrusive management actions other than possibly thin-layer capping (Merritt et al., 2010).

\section{ACKNOWLEDGMENT}

I thank Denis Moledo de Souza Abessa for inviting me to write this Short Commentary.

\section{REFERENCES}

BRIDGES, T.S., GUSTAVSON, K.E., SCHROEDER, P., ELLS, S.J., HAYES, D., NADEAU, S.C., PALERMO, M.R. \& PATMOT, C. 2010. Dredging processes and remedy effectiveness: relation to the $4 \mathrm{Rs}$ of environmental dredging. Integr Environ Assess Manag. 6(4): 619-630. http://dx.doi.org/10.1002/ieam.71.

CHAPMAN, P.M. 2007. Determining when contamination is pollution - weight of evidence determinations for sediments and effluents. Environment International. 33(4): 492-501. https://doi. org/10.1016/j.envint.2006.09.001.

CHAPMAN, P.M. 2008. Environmental risks of inorganic metals and metalloids: a continuing, evolving scientific odyssey. Human Ecol Risk Assess. 14(1): 5-40. https://doi org/10.1080/10807030701790272.

CHAPMAN, P.M. 2016. Environmental quality benchmarks - the

Table 1. Positive and negative aspects of the different sediment remediation alternatives

\begin{tabular}{|c|c|c|}
\hline Sediment remediation alternative & Positive aspects & Negative aspects \\
\hline No action (other than monitoring) & $\begin{array}{l}\text { No disturbance of existing aquatic } \\
\text { habitat } \\
\text { No sediment resuspension, loss, or } \\
\text { disposal issues }\end{array}$ & $\begin{array}{l}\text { Use of area may be restricted with } \\
\text { potential economic impacts }\end{array}$ \\
\hline In situ treatment & $\begin{array}{c}\text { No sediment resuspension, loss, or } \\
\text { disposal issues }\end{array}$ & $\begin{array}{c}\text { Only sediment surface treated } \\
\text { Disturbance of existing aquatic habitat } \\
\text { Use of area may be restricted with } \\
\text { potential economic impacts }\end{array}$ \\
\hline Capping & $\begin{array}{c}\text { No sediment resuspension, loss, or } \\
\text { disposal issues }\end{array}$ & $\begin{array}{c}\text { Disturbance of existing aquatic habitat } \\
\text { Possible effects on navigation (altered } \\
\text { sediment depth) }\end{array}$ \\
\hline Dredging & $\begin{array}{l}\text { Most, but not all, contamination } \\
\text { removed (Bridges et al., 2010) }\end{array}$ & $\begin{array}{c}\text { Disturbance of existing aquatic habitat } \\
\text { Sediment resuspension, loss, transport } \\
\text { and disposal issues }\end{array}$ \\
\hline
\end{tabular}


good, the bad, the ugly. Environ Sci Pollut Res. https://doi. org/10.1007/s11356-016-7924-2.

CHAPMAN, P.M. \& SMITH, M. 2012. Assessing, managing and monitoring contaminated aquatic sediments. Mar Pollut Bull. 64(10): 2000-2004. https://doi.org/10.1016/j. marpolbul.2012.07.023.

CHAPMAN, P.M., WANG, F., JANSEN, C., PERSOONE, G. \& ALLEN, H. 1998. Ecotoxicology of metals in aquatic sediments: binding and release, bioavailability, hazard, risk and remediation. Can J Fish Aquat Sci. 55(10): 2221-2243. https:// doi.org/10.1139/cjfas-55-10-2221.

ENVIRONMENT AND CLIMATE CHANGE CANADA. 2017. Saint Lawrence River Area of Concern. https://www.ec.gc.ca/ raps-pas/default.asp?lang=En\&n=2AB8023B-1

FUCHSMAN, P.C., BELL, K.S., MERRITT, K.A., CONDER, J.M., CHADWICK, J.M., BRIDGES, T.S. \& MAGAR, S. 2014. Monitored natural recovery. In: Reible, D. (ed), Processes, Assessment and Remediation of Contaminated Sediments.
SERDP ESTCP Environmental Remediation Technology, Vol 6. USA (New York, NY): Springer, pp 227-262. https://doi. org/10.1007/978-1-4614-6726-7_9.

MAGAR, S. \& WENNING, R.J. 2006. The role of monitored natural recovery in sediment remediation. Integr Environ Assess Manag. 2(1): 66-74. https://doi.org/10.1002/ieam.5630020112.

MAGAR, V.S., CHADWICK, D.B., BRIDGES, T.S., FUCHSMAN, P.C., CONDER, J.M., DEKKER, T.J., STEEVENS, J.A., GUSTAVSON, K.E. \& MILLS, M.A. 2009. Technical guide: Monitored natural recovery at contaminated sediment sites. Environmental Security Technology Certification Project ER0622, 276 pp. https://clu-in.org/download/contaminantfocus/ sediments/ER-0622-MNR-FR.pdf.

MERRITT, K.A., CONDER, J., KIRTAV, V., CHADWICK, D.B. \& MAGAR, V. 2010. A review of thin-layer placement applications to enhance natural recovery of contaminated sediment. Integr Environ Assess Manage. 6(4): 749-760. https://doi.org/10.1002/ ieam.76. 